\title{
DEGRADATION OF POLYCYCLIC AROMATIC HYDROCARBONS USING BACTERIAL ISOLATE FROM THE CONTAMINATED SOIL AND WHITE ROT FUNGUS PLEUROTUS OSTREATUS
}

\author{
ACEVEDO-SANDOVAl, O ${ }^{1}{ }^{1}$ - GutIÉRREZ-AlCANTARA, E. J. ${ }^{2}$ - PEREZ-BALAN, R. ${ }^{2}$ - ROdRÍGUEZ- \\ VÁZQUEZ, G. ${ }^{3}$-ZAMORATEGUI-MOLINA, A. ${ }^{3}$ - TIRADO-TORRES, D. ${ }^{3 *}$ \\ ${ }^{1}$ División de Investigación, Desarrollo e Innovación, Universidad Autónoma del Estado de \\ Hidalgo, km 4.5 Pachuca-Actopan, Torres de Rectoría $4^{\circ}$ piso, Pachuca, Hgo., México \\ ${ }^{2}$ Facultad de Ciencias Químico-Biológica, Universidad Autónoma de Campeche \\ Av. Agustín Melgar S/N, Buena Vista, CP: 24039, Campeche, Cam., México \\ ${ }^{3}$ Departamento de Ingeniería Civil, División de Ingenierías, Campus Guanajuato, Universidad de \\ Guanajuato, Av. Juarez N 77, Col. Centro, Guanajuato, Gto., México \\ *Corresponding author \\ e-mail:d.tirado@ugto.mx \\ (Received $21^{\text {st }}$ Feb 2018; accepted 21 ${ }^{\text {st }}$ May 2018)
}

\begin{abstract}
The use of microbial consortia composed of bacteria and fungi presents higher rates of polycyclic aromatic hydrocarbon $(\mathrm{PAH})$ degradation and is, therefore, essential for the remediation of contaminated soils. A microbial consortium compound comprising Ochrobactrum intermedium and white rot fungus Pleurotus ostreatus was found to be capable of degrading PAHs of crude oil in soil. This research studied the degradation capacity of a consortium composed of $O$. intermedium and $P$. ostreatus and the degradation capacity of both the bacteria and the fungus individually. The soil was artificially contaminated using two crude oil concentrations corresponding to 86,000 and $172,000 \mathrm{mg} \mathrm{kg}^{-1}$. The concentrations of PAHs extracted from the two concentrations of crude oil were 138.16 and $268.03 \mathrm{mg} \mathrm{kg}^{-1}$, respectively, with respective extraction resins of 78.3 and $73.5 \%$. In total, the biodegradation of $10 \mathrm{PAHs}$ were studied. Fluoranthene, indene[1,2,3-cd]pyrene and benzo[g,h,i]perylene were completely removed by the consortium after 50, 80 and $50 \mathrm{~d}$ of incubation, respectively. The rate at which anthracene, pyrene, chrysene and benzo[a]anthracene biodegraded in the presence of the microbial consortium were $96 \%, 86 \%, 98 \%$ and $98 \%$, respectively, after $110 \mathrm{~d}$ of incubation. In this study, higher rates of degradation were obtained with the consortium than when the components were used individually, showing that consortia composed of fungi and bacteria are an efficient technology for degrading xenobiotics, as is the case with PAHs.
\end{abstract}

Keywords: PAHs, soil microcosm, microbial consortium, biodegradation, white-rot fungi

\section{Introduction}

The most resistant components of petroleum, polycyclic aromatic hydrocarbons (PAHs) are environmentally problematic due to their toxic, mutagenic and carcinogenic properties (Sahoo et al., 2012; Sinha et al., 2012). Low molecular weight (LMW) PAHs exhibit highly toxic characteristics and affect reproduction rates and mortality in aquatic biota, while high molecular weight (HMW) PAHs have higher mutagenic and carcinogenic effects in living beings (Boonchan et al., 2000). There are different transformation pathways for PAHs in nature, such as volatilization, adsorption, photooxidation, chemical oxidation, bioaccumulation and microbial degradation (Yuan et al., 2002). Soil is one of the abiotic resources most affected by PAH pollution. Physicalchemical technologies are generally used to reduce PAH soil contamination, although they have drawbacks, among which are their high cost, difficulty of operation and generation of secondary contaminants (Mamma et al., 2004). Bioremediation is an 
economical and efficient method for both eliminating PAHs from the soil and reducing the toxicity of the medium (Frenzel et al., 2010).

The bioremediation technology is based on the use of the catabolic ability of microorganisms using xenobiotics as energy sources. Successful bioremediation requires microorganisms with the capacity to degrade the contaminant (Venosa and Zhu, 2003). The application of isolated pure microorganisms or microbial consortia that have the ability to degrade PAHs and which have been taken from contaminated sites represents a possible alternative for the bioremediation of contaminated sites with similar environmental characteristics if the soil lacks the microbial flora capable of degrading the contaminant (Liu et al., 2011). Numerous studies have focused on degrading PAHs to deal with environmental pollution, reporting the use of a large number of species, with the most studied genera being pseudomonas, mycobacterium, alcanivorax, sphingomonas, microbulbifer, shingomonas, micrococcus, cellulomonas, gordonia, and penicillium, among others (Brito et al., 2006; Vila et al., 2010). Fungi genera such as Chrysosporium, Bjerkandera, Irpex, Agrocybe, Lentinus, Pleurotus and Trametes are among those that are reported to have been used (Valentín et al., 2006; Chupungars et al., 2009).

Although various studies have been able to degrade PAHs using pure microorganisms, these results can be improved through the use of microbial consortia (Bacosa et al., 2010; Colombo et al., 2011) and bacteria-fungus consortia (Boonchan et al., 2000; Li et al., 2008). One of the advantages of using microbial consortia is their multiple metabolic capacities, which increase the efficiency of the degradation process (Ghazali et al., 2004), the degradation of PAHs with consortia formed by using bacteria-fungus is a very promising technique because of the beneficial characteristics of both kingdoms. Thus, the aim of this study was to evaluate the capacity of the consortium formed by Ochrobactrum intermedium and Pleurotus ostreatus to degrade PAHs in a microcosm of soil contaminated with oil, with the objective of achieving superior remediation results than those achieved with individual microorganisms.

\section{Materials and methods}

\section{Chemicals}

The crude oil used in this study was obtained from the Lázaro Cardenas refinery in Minatitlán, Veracruz, Mexico. The chemicals used in the extraction and cleaning of the PAHs were of analytical grade, while the chemicals used in the quantification of the PAHs were of an HPLC grade, with both procured from Sigma-Aldrich (USA).

\section{Microorganisms and culture medium}

The bacterium was isolated from sediments in a hydrocarbon contaminated creek in Poza Rica, Veracruz, Mexico, at a depth of $40 \mathrm{~cm}$ from a site constantly polluted by oil, located at coordinates $20^{\circ} 32^{\prime} 28.77^{\prime} \mathrm{N}$ and $97^{\circ} 28^{\prime} 02.60^{\prime \prime} \mathrm{O}$. Bushnell Haas medium (BHM) was used as the culture medium in this study, with the following composition: ( $\mathrm{g}$ $\left.l^{-1}\right): 2 \mathrm{NH}_{4} \mathrm{NO}_{3} ; 2 \quad \mathrm{KH}_{2} \mathrm{PO}_{4} ; 2 \quad \mathrm{~K}_{2} \mathrm{HPO}_{4} ; 1 \mathrm{NaCl}$; and, $0.2 \mathrm{MgSO}_{4} .7 \mathrm{H}_{2} \mathrm{O}$. The micronutrients used were $\left(\mathrm{mg} \mathrm{l} \mathrm{l}^{-1}\right): 1 \mathrm{CaCl}_{2} \cdot 2 \mathrm{H}_{2} \mathrm{O} ; 1 \quad \mathrm{MnSO}_{4} \cdot \mathrm{H}_{2} \mathrm{O} ; 1 \quad \mathrm{FeCl}_{3} ; 0.5$ $\mathrm{ZnSO}_{4} .7 \mathrm{H}_{2} \mathrm{O}$; and, $2 \mathrm{CuSO}_{4}$. The $\mathrm{pH}$ was adjusted to 7.0 using $10.5 \mathrm{M} \mathrm{NaOH}$. The BHM was sterilized by autoclaving at $121^{\circ} \mathrm{C}$ for $15 \mathrm{~min}$. P. ostreatus (ATCC38540) was grown in darkness on a potato dextrose agar (PDA) plate at $27^{\circ} \mathrm{C}$ for $3 \mathrm{~d}$. 


$$
\text { - } 3817 \text { - }
$$

\section{Enrichment and isolation of the PAH-degrading bacterium}

The pre-enrichment medium used to isolate the PAH-degrading bacterium was BHM with dextrose $(1 \mathrm{~g})$ as a carbon source. The inoculated flasks were incubated in darkness for seven days at $30{ }^{\circ} \mathrm{C}$ at $150 \mathrm{rpm}$, after which $10 \mathrm{ml}$ of said culture was transferred to a flask containing $90 \mathrm{ml}$ of BHM supplemented with $1 \mathrm{~g}$ of dextrose and $1 \mathrm{~g}$ of oil as carbon sources. The flasks were then incubated under the same conditions described above, with the procedure then undertaken five further times using $1 \mathrm{~g}$ of petroleum as a unique carbon source. The PAH-degrading bacterium was isolated via enrichment, using Maya crude oil, while the isolation of the strain was carried out on nutrient agar plates by means of conventional spread-plate techniques, with the plates incubated at $30{ }^{\circ} \mathrm{C}$ for 48 $\mathrm{h}$. The isolated strain was stored at $-20^{\circ} \mathrm{C}$ in liquid culture containing $20 \%$ glycerol $(\mathrm{v} / \mathrm{v})$. The PAH-degradation capacity of the isolated strain was determined by means of a qualitative evaluation. Petri dishes with BHM agar and oil as a carbon source were inoculated with $1 \mathrm{ml}$ of isolated strain culture and incubated in darkness at $30^{\circ} \mathrm{C}$ for $72 \mathrm{~h}$. A Petri dish without inoculate served as a control to determine the loss of hydrocarbons due to abiotic factors (Bacosa et al., 2013). The emulsification capacity was evaluated by adding $10 \mathrm{ml}$ of the bacterial culture after $48 \mathrm{~h}$ of incubation to an Erlenmeyer flask containing $90 \mathrm{ml}$ of BHM supplemented with $2 \mathrm{ml}$ of oil and $1 \mathrm{ml}$ of Tween 80 . An uninoculated control flask was also used. All flasks were incubated in darkness at $30{ }^{\circ} \mathrm{C}$ in an orbital shaker set to $150 \mathrm{rpm}$. Each assay was performed in triplicate.

\section{The 16S rRNA sequence analysis of isolated strain}

The cells of the strain were grown in $50 \mathrm{ml}$ Luria Bertani medium at $30{ }^{\circ} \mathrm{C}$ in darkness for one night. DNA was extracted according to Sambrook and Roussell (2001). To amplify the 16S rDNA gene, a polymerase chain reaction (PCR) was performed using two universal primers, the forward primer Eu 530F (5'-TGA CTG ACT GAG TGC CAG GAC CCG CGG-3') and the reverse primer Eu 1449R (5'-TGA CTG ACT GAG GCT ACC TTG TTA CGA CTT-3'), described by Borneman et al. (1996). Each $50 \mu 1$ reaction contained the following: $3 \mu \mathrm{l}$ of DNA template; $0.25 \mu \mathrm{l}$ of Eu 530F; $0.25 \mu \mathrm{l}$ of Eu 1449R (final concentration $20 \mathrm{pmol}$ ); $25 \mu \mathrm{l}$ of master mix (Vivantis); $0.5 \mu 1$ of $\mathrm{MgCl}_{2}$ (final concentration $2.0 \mathrm{mM} / \mathrm{L}$ ); and, $21 \mu \mathrm{l}$ of water. The PCR mixtures were preheated in Eppendorf Mastercycler EP Gradient thermal cycler at $95{ }^{\circ} \mathrm{C}$ for 5 min prior to running the following cycles: $95{ }^{\circ} \mathrm{C}-1 \mathrm{~min} ; 55^{\circ} \mathrm{C}-1 \mathrm{~min}$; and, $72{ }^{\circ} \mathrm{C}-1 \mathrm{~min}$. The reactions were conducted for 30 cycles in a DNA thermal cycle. After the last cycle had been completed, a chain-elongation step was carried out at $72{ }^{\circ} \mathrm{C}$ for $5 \mathrm{~min}$. The amplified DNA was sequenced by the Macrogen Company (Korea). The sequence was subjected to a BLAST similarity search on the NCBI-USA website (http://www.ncbi.nlm.nih.gov) and deposited into GenBank. Many relevant 16S rDNA gene sequences with authenticated and published names were selected as references from Gen-Bank, while the phylogenetic tree was constructed using the MEGA 6.0 software.

\section{Experimental design}

The degradation of PAH in a soil microcosm by the microbial consortium consisting of $P$. ostreatus and isolated bacteria was evaluated via the application of a $3 \times 3 \times 2$ factorial design, using controls comprising contaminated soil and soil contaminated with substrate, both without inoculum, while each treatment was performed in triplicate. The bacterial degradation was determined using $50 \mathrm{~g}$ of sieved soil $(2 \mathrm{~mm})$ placed into 
glass bottles $(150 \mathrm{ml})$, while the fungal and consortium degradation were assessed in $40 \mathrm{~g}$ of sieved soil and $10 \mathrm{~g}$ of substrate (corn stubble and coffee pulp 1: 1, w: w) to obtain a final weight of $50 \mathrm{~g}$. The moisture content was adjusted to $70 \%$, while the molar ratio C: N: P was 100: 10: 1 . All soil samples were autoclaved for 60 minutes at $121{ }^{\circ} \mathrm{C}$. 4.3 with $8.6 \mathrm{~g}$ of crude oil added dropwise to each bottle to achieve uniform distribution and final concentrations of 86,000 and $172,000 \mathrm{mg}$ of total petroleum hydrocarbons $\mathrm{kg}^{-1}$ soil. $30 \mathrm{ml}$ of acetone was then added, after which a homogeneous mixture of the soil was obtained. $30 \mathrm{ml}$ of acetone was added to homogenize the soil with the oil of the soil, after which the acetone was completely evaporated from the glass bottles. Then, $3 \mathrm{ml}$ of bacterial inoculum $\left(3.2 \times 10^{8} \mathrm{CFU} / \mathrm{ml}\right)$ was added to a set of bottles containing $50 \mathrm{~g}$ of soil, while another set of bottles contained $40 \mathrm{~g}$ of soil and $10 \mathrm{~g}$ of substrate invaded with the consortium, and the third set of bottles contained only $40 \mathrm{~g}$ of soil and $10 \mathrm{~g}$ of substrate invaded with mycelium of P. ostreatus. All bottles were incubated at $30^{\circ} \mathrm{C}$ in the dark, under three different incubation times $(50,80$ and $110 \mathrm{~d})$.

\section{PAH extraction and analytical methods and data analysis}

The extraction of PAHs was undertaken in accordance with Li et al. (2008), with the soil dried and passed through a 60-mesh sieve, and approximately $2 \mathrm{~g}$ of dry soil placed in a $50 \mathrm{~mL}$ test tube, to which $15 \mathrm{~mL}$ of acetone:dichloromethane (1:5) mixture was added. The PAHs were extracted via sonication for $40 \mathrm{~min}$ in an ultrasonic bath (Brand Branson, MH Series, MOD 1800), after which two extractions were taken from each sample and the supernatants then mixed. The extracts were concentrated in a rotary evaporator and resuspended in $2 \mathrm{ml}$ of cyclohexane. For the cleaning, $2 \mathrm{ml}$ of the sample resuspended in cyclohexane was eluted with $15 \mathrm{ml}$ of a dichloromethane:hexane mixture (2:3) through a C-18 cartridge. The eluate was concentrated and resuspended in $2 \mathrm{ml}$ of acetonitrile (Tian et al., 2008), while the characterization of residual PAH in the soil after the completed incubation times was performed using an Agilent 1260 HPLC System with a diode array and fluorescence detectors. The separation of the 16 PAHs was carried out on a ZORBAX Eclipse PAH (4.6 mm x $50 \mathrm{~mm}, 1.8 \mu \mathrm{m})$ column. The mobile phase comprised an acetonitrile:water mixture (60:40), a flow rate of $0.8 \mathrm{~mL} / \mathrm{min}$, a sample volume of $20 \mu \mathrm{l}$, and a run time of $16 \mathrm{~min}$. The data was recorded as means \pm standard deviation. One-way analysis of variance (ANOVA) was conducted to determine the significant differences in the degradation of the PAHs by microorganisms at different time periods. The differences between treatments were analyzed via a Tukey (HSD) test using the SAS 9.0 software. Differences between means at a level of $5 \%(\mathrm{P}<0.05)$ were considered significant.

\section{Results and discussion}

\section{Degradation of PAHs by O. intermedium}

Figure 1 shows the biodegradation of PAHs by $O$. intermedium, P. ostreatus and the consortium of both microorganisms. When the PAH concentration was $138 \mathrm{mg} \mathrm{kg}^{-1}$, during the $80 \mathrm{~d}$ of incubation, a linear degradation was observed, while an increase in the rate of degradation was observed after $80 \mathrm{~d}$ of incubation. During the incubation of Control A, soil contaminated with oil without inoculum, a slight decrease of nonsignificant PAHs was observed. A trend of increasing degradation was observed at 
$268 \mathrm{mg} \mathrm{kg}^{-1} \mathrm{PAH}$. As with Control A, Control B did not present a significant decrease of PAHs. This study found that $O$. intermedium has a higher rate of degradation when exposed to a concentration of $268 \mathrm{mg} \mathrm{kg}^{-1}$ of PAHs, and offers higher degradation potential the longer the incubation time, with the degradation trend presenting a constant drop along with falling PAH concentrations (Tirado-Torres et al., 2017). Cerqueira et al. (2011) observed that the most challenging method of PAH elimination is that which uses microorganisms.

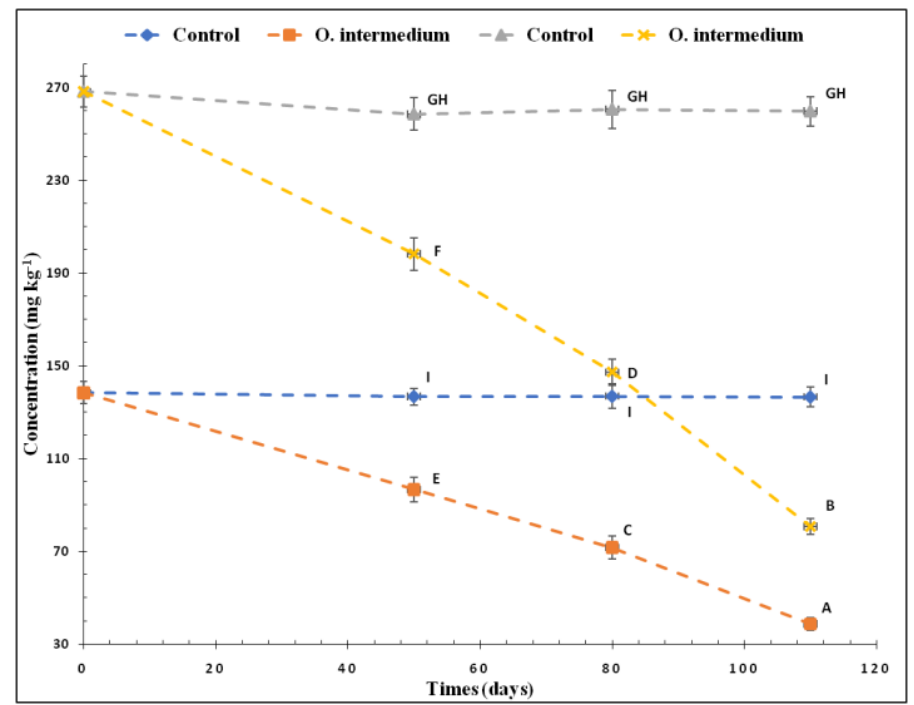

Figure 1. Changes in the concentrations of PAHs during biodegradation in crude oil PAHcontaminated soils. Control: Sterile soil without inocula. Letters represent significant differences among treatments (Tukey, $P<0.05$ )

Limited by the low bioavailability of high molecular weight compounds, native microbial flora has a low capacity to remove PAHs from contaminated soils. Therefore, soil remediation processes are extremely complex in the case of hydrocarbon contamination (Janbandhu and Fukelar, 2011). The isolation of certain microorganisms with the ability to degrade PAHs has enabled significant progress in the development of bioaugmentation techniques and soil remediation (Mao et al., 2012). While few studies of $O$. intermedium have been conducted and especially research seeking to verify its potential to degrade PAHs, it is well known that microorganisms producing biosurfactants present a better option for the bioremediation of contaminants with hydrophobic characteristics, such as hydrocarbons, given that they increase their bioavailability (Wang et al., 2008).

In this study, $O$. intermedium was isolated and adapted to degrade oil PAHs in contaminated soils. Previous studies were reported to use $O$. intermedium isolated from the rhizosphere in soils contaminated by heavy metals and that it has the ability to reduce metal contaminants and subsist in contaminated soils (Sultan and Hasnain, 2007; Waranusantigul et al., 2011). Recently, a study carried out in a liquid medium proved that the species produces biosurfactants with a high level of thermal stability and tolerance to extreme levels of salinity and, thus, able to degrade up to $40 \%$ of PAHs in sludge contaminated with oil, while, in soil, the microcosms are able to degrade $70 \%$ of the most hydrophobic compounds in only three weeks (Bezza et al., 2015). 


\section{Degradation of PAHs by P. ostreatus}

Figure 2 shows the action of $P$. ostreatus on PAHs in soils contaminated with oil during incubation at 50,80 and $110 \mathrm{~d}$ in this study. Compared to control assays, $P$. ostreatus presented significant degradation rates at concentrations of $138 \mathrm{mg} \mathrm{kg}^{-1}$, at which a constant degradation between 80 and $110 \mathrm{~d}$ of incubation was observed. $P$. ostreatus was observed to significantly degrade PAHs at concentrations of $268 \mathrm{mg} \mathrm{kg}^{-1}$. An adaptation stage was observed to occur during the first $50 \mathrm{~d}$, while, at 80 and $110 \mathrm{~d}$, a linear decreasing trend was observed, signifying a higher rate of degradation.

Initially, the study of the degradation potential of microorganisms was given on a laboratory scale and mainly comprised degradation tests on liquid culture. Earlier studies found that the $P$. ostreatus strain ATCC38540 is highly efficient in degrading PAHs in liquid culture (Tirado-Torres et al., 2016). Therefore, this study inoculated $P$. ostreatus in soil contaminated with petroleum to study its capacity to degrade the PAHs present in the crude oil.

P. ostreatus was able to degrade up to $115.2 \mathrm{mg} \mathrm{kg}^{-1}$ of a PAH concentration of $138.3 \mathrm{mg} \mathrm{kg}^{-1}$ and 186.2 of $268.2 \mathrm{mg} \mathrm{kg}^{-1}$ after $110 \mathrm{~d}$ of incubation compared to the respective control. During the first $50 \mathrm{~d}$ of remediation, the PAH elimination efficiency was attributed to the sorption of the contaminant in the co-substrate added to the treatment, plus the soil particles (Johnsen et al., 2005). At 80 and $110 \mathrm{~d}$, the elimination of PAHs was attributed to the release of ligninolytic enzymes produced by P. ostreatus to break the cellulose of the co-substrate, since at those it was observe traces of cosubstrate and an increase of the biomass of $P$. ostreatus. This suggests that the addition of the co-substrate enabled the fungus to execute an efficient cometabolic process (Bouchez et al., 1999).

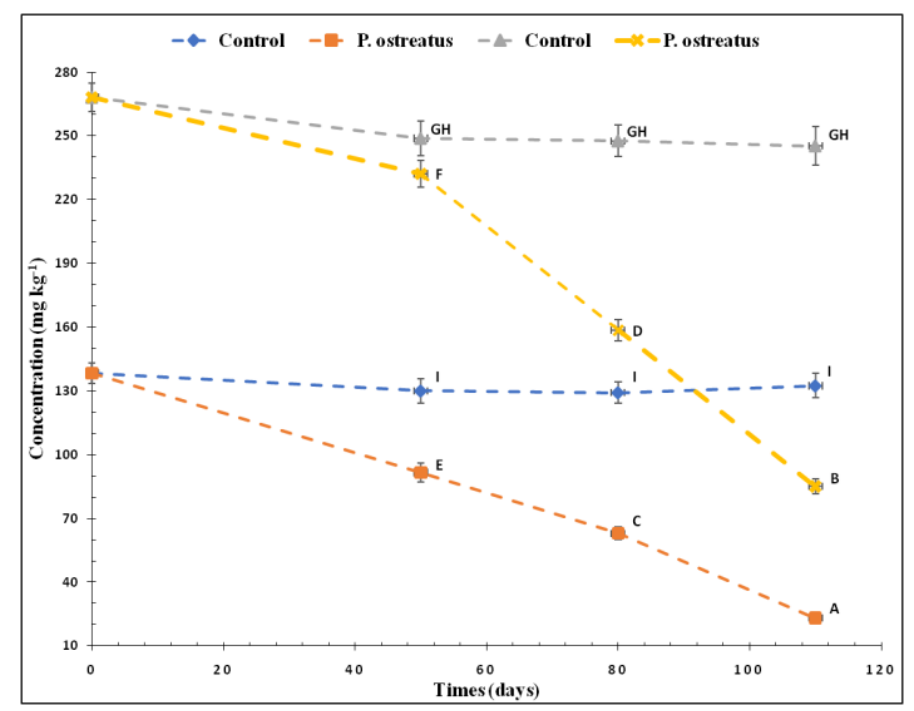

Figure 2. Concentrations of PAHs during biodegradation in crude oil PAH-contaminated soils for fungus. Control: Sterile soil without inocula. Letters represent significant differences among treatments (Tukey, $P<0.05$ )

Basidiomycetes act by means of extracellular enzymes in the co-metabolism process, during which these extracellular compounds act on the contaminant (Namhyun et al., 2000). White-rot fungi are basidiomycetes with the capacity to generate extracellular 
enzymes such as laccase, lignin peroxidase and manganese peroxidase, which are found to obtain good results in the degradation of xenobiotic agents (Hatakka, 1994). Acevedo et al. (2011), studied the efficacy of eliminating PAHs with a Chilean white-rot fungus (Anthracophyllum discolor) in contaminated soil, finding that $A$. discolor showed a high $\mathrm{PAH}$ removal capacity associated with the production of the extracellular enzyme MnP, results which are comparable with the ability of $P$. ostreatus to degrade PAHs as they are both white-rot fungi. In previous studies conducted in liquid culture, the presence of PAHs has been shown to stimulate MnP production in P. ostreatus (Bezalel et al., 1996). The production of ligninolytic enzymes by white-rot fungi, as well as other biochemical molecules, is known to facilitate the removal of xenobiotic agents such as PAHs (Baldrian et al., 2008).

\section{Degradation of PAHs by $O$. intermedium-P. ostreatus consortium}

This section presents the residual concentrations of PAHs in contaminated soils during the biodegradation induced by the consortium formed by $O$. intermedium and $P$. ostreatus (Fig. 3). As observed, after the inoculation of the consortium, the PAHs were efficiently degraded by $110 \mathrm{~d}$, attaining a degradation efficiency of 86.7 and $75.5 \%$ for the PAH concentrations of 138 and $268 \mathrm{mg} \mathrm{kg}^{-1}$, respectively.

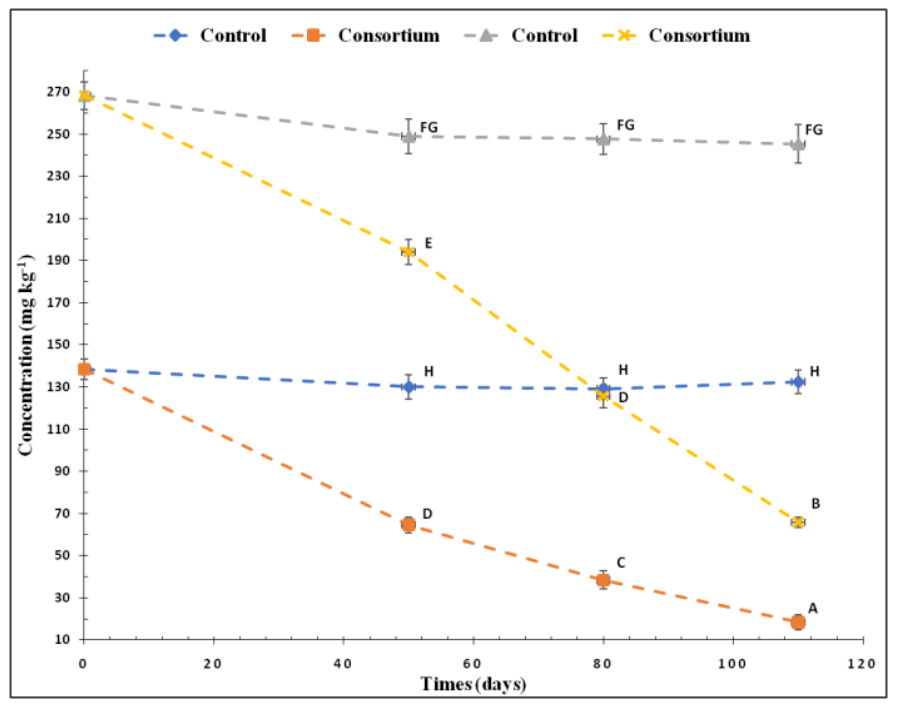

Figure 3. Concentrations of PAHs during biodegradation in crude oil PAH-contaminated soils for consortium. Control: Sterile soil without inocula. Letters represent significant differences among treatments (Tukey, $P<0.05$ )

While the consortium was observed to present a high rate of degradation at $138 \mathrm{mg}$ $\mathrm{kg}^{-1}$ of PAHs after $50 \mathrm{~d}$ of incubation, a decrease in degradation efficiency occurs between 80 and $110 \mathrm{~d}$. However, the consortium requires less time to adapt to the contaminated environment than the organisms used separately. At PAH concentrations of $268 \mathrm{mg} \mathrm{kg}^{-1}$, the consortium presented similar behavior to that obtained at $50 \mathrm{~d}$ of incubation with $138 \mathrm{mg} \mathrm{kg}^{-1}$ of PAHs. An increase in the degradation response is observed between 50 and $80 \mathrm{~d}$ of incubation, while a decrease in the rate of degradation is observed between 80 and $110 \mathrm{~d}$ due to the decreasing concentration of PAHs. These results demonstrate that the consortium presents a greater degradation capacity in the 
first $80 \mathrm{~d}$ of remediation than the microorganisms in their isolated form. This part of the study reveals that $O$. intermedium and $P$. ostreatus act in synergy to efficiently metabolize PAHs from contaminated soil.

In this study, the consortium proved to have a greater capacity to degrade soil PAHs due to the synergism between the two microorganisms, which facilitates the degradation of PAHs. The consortium removed 119.9 and $202.4 \mathrm{mg} \mathrm{kg}^{-1}$ of PAHs at respective concentrations of 138.3 and $268.2 \mathrm{mg} \mathrm{kg}^{-1}$ in soil at $110 \mathrm{~d}$ of incubation. This is attributed to the enzymatic activity of the fungus, which formed a habitat that was less toxic to the bacteria (Chagas-Spinelli et al., 2012). Basidiomycetes normally synthesize enzymes that, to an extent, degrade complex PAHs (Sack et al., 1997; Aranda et al., 2010). Bacteria that generate enzymes such as laccase can contribute to an improved degradation of PAHs (Zeng et al., 2010). At $110 \mathrm{~d}$ of incubation at the two concentrations handled in this study, it was observed that the consortium achieved the highest level of PAH removal, while the other two treatments achieved levels close to the degradation rate of the consortium. This can be attributed to the limitation of nutrients necessary for the consortium (Hollender et al., 2003), while limiting the source of energy can also affect the efficiency of microorganisms (Kim et al., 2009). The consortium's efficiency in degrading PAHs is due to the qualities of the co-metabolism generated by $P$. ostreatus, as initiated by the addition of co-substrate, which, when decomposed by the extracellular enzymes expelled by the fungus, releases nutrients outside the cell that are available both for their products and for the bacteria (Šnajdr et al., 2011).

In addition, bacteria are able to form biofilms around fungal hyphae in order to bridge pores and penetrate soil aggregates (Kohlmeier et al., 2005). Fungi can also actively take and transfer PAHs through their hyphae via the cytoplasmic stream (Furuno et al., 2012). The primary degradation strategy carried out by fungi and bacteria comprises the release of biosurfactants in order to obtain greater contaminant bioavailability (Johnnsen and Karlson, 2004; Bento et al., 2005). The strong competitive capacity of a particular fungal species is considered a premise of successful soil colonization (Baldrian, 2008). Although, in this study, P. ostreatus has been shown to coexist with $O$. intermedium, other studies have reported decreasing $P$. aeruginosa biomass when forming a consortium with $P$. ostreatus (Tornberg et al., 2003). In contrast, Federici et al. (2007) observed an increase in bacterial counts of mycobacterium, nocardia and rhodococcus when used in consortium with $P$. ostreatus (DeBruyn et al., 2007). It should be noted that interactions between fungi and bacteria can positively affect biodegradation applied metabolically in conjunction with a fungal co-metabolism (Mueller et al., 1989), as well as negatively affecting the degradation of PAHs in soil (Borras et al., 2010). In some cases, the use of consortia has not obtained results showing the potential to degrade xenobiotics (Tornberg et al., 2003), while, in other cases, the positive cohabitation of consortium has been obtained with high rates of PAH degradation (Federici et al., 2007).

In this study, the consortium degraded 75.5 to $86.7 \%$ of PAHs, while Gallego et al. (2007) observed that a microbial consortium degraded from 31 to 55\% of PAHs. It should be reiterated that, as Toledo et al. (2006) state, the comparison of results varies greatly due to the concentrations of hydrocarbons and the incubation times obtained. In another successful study of consortia, Díaz-Ramirez et al. (2008) formed a microbial consortium of six strains which, after $18 \mathrm{~d}$ of incubation, degraded $31 \%$ of PAHs. Ruberto et al. (2006) found that a combination of bioaugmentation and biostimulation in 
a microbial consortium caused a $46.6 \%$ elimination of $1,744 \mathrm{mg} \mathrm{kg}^{-1}$ of phenanthrene in soil after 56 days of incubation in Antarctic soil. The results obtained in this study show that fungal and bacterial consortia can be an efficient technology for degrading xenobiotics, as is the case for PAHs.

\section{Bioremediation treatments: individual PAH removal}

Previous studies have reported that microbial consortia obtain higher degradation efficiencies in liquid culture with the addition of surfactants in order to increase the bioavailability of xenobiotics (Bautista et al., 2009; Molina et al., 2009; González et al., 2011). The present study was carried out in soil without the addition of surfactants in order to observe the capacity of the consortium without needing to apply biostimulation. Sixteen PAHs were used in this study, of which six were not detected in the initial treatment period: acenaphthene (ACE); Acenaphthylene (ACY); benzo [b] fluoranthene $(\mathrm{BBF})$; benzo [k] fluoranthene (BKF); Benzo [a] pyrene (BaP); and, dibenzo [a, h] anthracene (DahA). Table 1 shows the 10 compounds detected in the chromatographic analysis and the degradation efficiencies obtained by the treatments at 110 days of incubation under a constant temperature of $30{ }^{\circ} \mathrm{C}$. It can be seen that the compounds which were completely removed by both the consortium and $P$. ostreatus are FLT, IND and $\mathrm{BgP}$. The compounds that showed significant degradation are ANT and $\mathrm{CHY}$, with removal efficiencies ranging from 96 to $98 \%$.

Table 1. Removal of individual PAH compounds in soil contaminated by crude oil after the 110-day incubation period for the three different treatments and two controls

\begin{tabular}{|c|c|c|c|c|c|c|c|}
\hline \multirow{2}{*}{ PAH } & \multirow{2}{*}{ Rings } & \multirow{2}{*}{$\begin{array}{c}\text { Initial } \\
\text { concentration } \\
\text { Mg.kg }^{-1}\end{array}$} & \multicolumn{5}{|c|}{ PAHs removed from treatments $(\%)$} \\
\hline & & & C-1 & $\mathrm{C}-2$ & O.I & P.O & C.O \\
\hline Naphthalene (NAP) & 2 & $74.16 \pm 2.3$ & $1.53 \pm 0.8_{\mathrm{d}}$ & $3.06 \pm 0.8_{\mathrm{d}}$ & $76.24 \pm 2.8_{\mathrm{c}}$ & $84.52 \pm 0.8_{\mathrm{b}}$ & $88.77 \pm 0.1_{a}$ \\
\hline Fluorene (FLU) & 2 & $27.83 \pm 0.1$ & $1.70 \pm 0.8_{\mathrm{d}}$ & $5.68 \pm 1.7_{\mathrm{c}}$ & $41.59 \pm 1.3_{b}$ & $69.77 \pm 0.6_{a}$ & $69.77 \pm 0.9 \mathrm{a}$ \\
\hline Fenanthrene (FEN) & 3 & $4.06 \pm 0.5$ & $1.31 \pm 0.9_{\mathrm{d}}$ & $0.28 \pm 0.1_{\mathrm{d}}$ & $69.74 \pm 0.6_{c}$ & $76.27 \pm 1.6_{b}$ & $85.23 \pm 1.7_{\mathrm{a}}$ \\
\hline Anthracene (ANT) & 3 & $7.43 \pm 0.1$ & $1.89 \pm 0.3_{\mathrm{d}}$ & $4.02 \pm 1.0_{\mathrm{c}}$ & $93.50 \pm 0.4_{b}$ & $92.50 \pm 1.4_{b}$ & $96.27 \pm 0.6_{\mathrm{a}}$ \\
\hline Total LMW & 2 y 3 & $113.48 \pm 1.8$ & $1.60 \pm 1.1_{d}$ & $3.71 \pm 0.9_{d}$ & $68.64 \pm 0.5_{c}$ & $81.13 \pm 1.3_{b}$ & $84.47 \pm 0.6_{a}$ \\
\hline Fluoranthene (FLT) & 4 & $6.75 \pm 0.1$ & $5.04 \pm 0.5_{\mathrm{c}}$ & $5.03 \pm 0.3_{\mathrm{c}}$ & $88.72 \pm 0.5_{b}$ & $100 \pm 0.0_{\mathrm{a}}$ & $100 \pm 0.0_{\mathrm{a}}$ \\
\hline Pyrene (PYR) & 4 & $4.77 \pm 0.4$ & $2.47 \pm 0.8_{\mathrm{e}}$ & $6.69 \pm 0.9_{\mathrm{d}}$ & $68.03 \pm 0.8_{\mathrm{c}}$ & $78.57 \pm 0.8_{\mathrm{b}}$ & $86.51 \pm 1.7_{\mathrm{a}}$ \\
\hline Chrysene (CHY) & 4 & $6.19 \pm 0.6$ & $2.83 \pm 0.8_{\mathrm{d}}$ & $1.87 \pm 0.5_{\mathrm{d}}$ & $94.63 \pm 0.6_{\mathrm{b}}$ & $91.60 \pm 1.4_{c}$ & $98.23 \pm 0.9 \mathrm{a}$ \\
\hline Benzo[a]anthracene (BaA) & 4 & $3.37 \pm 0.2$ & $5.14 \pm 0.7_{\mathrm{b}}$ & 8.59 v $0.8_{\mathrm{b}}$ & $98.08 \pm 0.8_{\mathrm{a}}$ & $95.67 \pm 1.3_{\mathrm{a}}$ & $98.18 \pm 0.5_{a}$ \\
\hline Indene[123-cd]pyrene (IND) & 5 & $1.44 \pm 0.1$ & $5.86 \pm 0.8_{\mathrm{d}}$ & $13.04 \pm 0.9_{\mathrm{c}}$ & $75.74 \pm 2.8_{b}$ & $100 \pm 0.0_{\mathrm{a}}$ & $100 \pm 0.0_{\mathrm{a}}$ \\
\hline Benzo[g,h,i]perylene (BgP) & 6 & $2.35 \pm 0.1$ & $4.69 \pm 0.5_{c}$ & $11.99 \pm 0.5_{b}$ & $97.59 \pm 1.5_{\mathrm{a}}$ & $100 \pm 0.0_{\mathrm{a}}$ & $100 \pm 0.0_{\mathrm{a}}$ \\
\hline Total HMW & 4 a 6 & $24.87 \pm 0.4$ & $4.80 \pm 0.9_{c}$ & $7.04 \pm 0.7_{c}$ & $87.31 \pm 1.8_{b}$ & $93.21 \pm 0.8_{a}$ & $96.73 \pm 0.4_{a}$ \\
\hline Total PAHs & & $138.35 \pm 5.42$ & $1.33 \pm 0.9_{\mathrm{d}}$ & $4.30 \pm 0.53_{d}$ & $72.04 \pm 0.5_{c}$ & $83.30 \pm 0.51_{b}$ & $86.69 \pm 0.21_{a}$ \\
\hline
\end{tabular}

Data are presented as mean $\pm \mathrm{SD}$. Means in the same row with a letter in common are not significantly different among treatments $(\mathrm{P}<0.05)$. C-1: Soil without inoculum C-2: Soil and cosubstrate without inoculum O.I: O. intermedium P.O: P. ostreatus C.O: O. intermedium-P. ostreatus

These results can be used for future studies of those compounds which have been totally eliminated. Figure 4 shows the degradation kinetics generated by the three treatments for each PAH. FLT was completely degraded after $80 \mathrm{~d}$ of treatment with both $P$. ostreatus and the consortium. IND was completely degraded after $50 \mathrm{~d}$ of treatment with the consortium, whereas treatment with $P$. ostreatus achieved complete degradation after $80 \mathrm{~d}$. $\mathrm{BgP}$, the aromatic compound used in this study with the greatest number of rings, was the PAH that was completely eliminated in less than $50 \mathrm{~d}$ of 
treatment with the consortium, whereas it was totally degraded after the $50 \mathrm{~d}$ of $P$. ostreatus treatment. The time required to obtain total degradation was shortest for $\mathrm{BgP}$, followed by IND and, finally, FLT. Several studies have concluded that petroleum components have different susceptibilities to degradation by microorganisms (Greenwood et al., 2008; Bacosa et al., 2010).

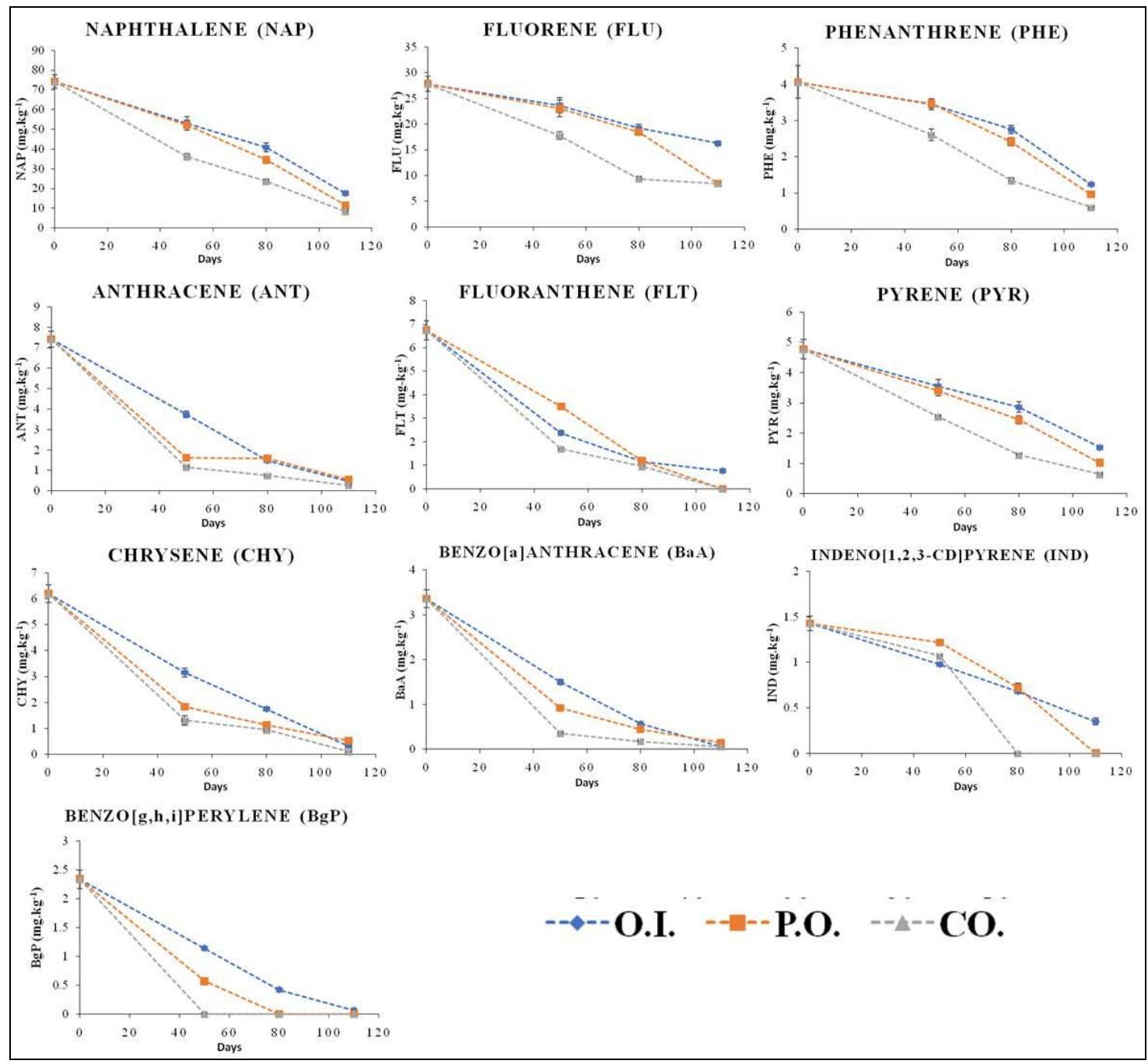

Figure 4. Concentration of individual PAH compounds during the 110-day experimental period for O.I. (O. intermedium), P.O. (P. ostreatus) and CO. (consortium) treatments

Degradation efficiencies of 69.7 to $85.2 \%$ PHE were obtained, proving that this compound can be degraded by actions associated with the microorganisms used in this study. Other studies using microorganisms have reported the biodegradation of PHE by such microorganisms as Sphingobacterium sp., Achromobacter sp., and Bacillus sp. (Janbandhu and Fulekar, 2011), while, in consortia, they have been able to degrade PHE at rapid rates without any additional carbon source (Arulazhagan and Vasudevan, 2009). Chagas-Spinelli et al. (2012), studied the degradation of PAHs via three treatments, including BSBA consortium, obtaining, after $126 \mathrm{~d}$ of incubation, degradation efficiencies similar to those found in this study. PAHs comprising two aromatic rings, 
such as NAP and FLU, achieved high degradation efficiencies, of 100 and $98.3 \%$, at concentrations of 2.1 and $12.3 \mathrm{mg} \mathrm{kg}^{-1}$, respectively. Although the concentrations used in the present study were much higher, the high degradation can be attributed to the fact that LMW-PAHs degrade more easily due to their lower hydrophobicity than those of HMW-PAHs (Lors et al., 2012).

The total degradation of FLT and IND was found to be possible in this research, results which are superior to those reported by Chagas-Spinelli et al. (2012), who obtained 86.6 and $93.9 \%$ degradation in their most effective treatment, with the FLT concentration 2.4 times lower and the IND concentration 4.4 higher than the concentrations used in this study. The efficiency of $O$. intermedium was found to be similar to that obtained by the research undertaken with the BSBA microbial consortium, whereas the consortium used in this study managed to eliminate both FLT and IND completely, meaning that the use of consortia formed by fungi and bacteria is more efficient than the microbial consortia. This is attributed to the ability of $P$. ostreatus to both generate extracellular enzymes and obtain greater xenobiotic bioavailability for microorganisms (Namhyun et al., 2000). As PYR is classified as an HMW, its degradation process is more difficult than that of LMWs. This compound has been previously studied in liquid culture using a microbial consortium, in which it was degraded by up to $80 \%$, although the increased $\mathrm{PAH}$ concentration decreased the degradation capacity of the consortium (Arulazhagan and Vasudevan, 2009). It is known that HMW PAHs, due to their high hydrophobicity, require longer degradation time and sometimes different microorganisms to degrade them (Luo et al., 2009; Boonchan et al., 2000). In this study, the concentrations of PYR were low so that its high degradation efficiencies had to be obtained by all three treatments. These results show that consortia composed of a bacteria-fungus mixture can more efficiently degrade existing LMW and HMW PAHs in soil (Li et al., 2008).

\section{Conclusions}

The consortium formed by certified $P$. ostreatus strain and $O$. intermedium strain isolated from soil contaminated with hydrocarbons were able to degrade PAHs in soil. The highest rate of degradation occurred using the consortium during the first 80 days of incubation, suggesting synergistic effects. In particular, the total degradation of HWM indene [1,2,3-cd] pyrene and benzo [g, h, i] perylene Haps was achieved using the consortium. The results of this study show that the consortium is a promising technology for the elimination of PAHs from soils contaminated with hydrocarbons; however, further research on the consortium must be undertaken through a field study as well as toxicity testing of the treated soils.

Acknowledgements. This study was financially supported by the Autonomous University of the State of Hidalgo. This research did not receive any specific grant from funding agencies in the public, commercial, or not-for-profit sectors.

\section{REFERENCES}

[1] Acevedo, F., Pizzul, L., Castillo, M. P., Cuevas, R., Diez, M. C. (2011): Degradation of polycyclic aromatic hydrocarbons by the Chilean White-rot fungus Anthracophyllum discolor. - Journal of Hazardous Materials 185: 212-219. 
[2] Aranda, E., Ullrich, R., Hofrichter, R. (2010): Conversion of polycyclic aromatic hydrocarbons, methyl naphthalenes and dibenzofuran by two fungal peroxygenases. Biodegradation 21: 267-281.

[3] Arulazhagan, P., Vasudevan, N. (2009): Role of a moderately halophilic bacterial consortium in the biodegradation of polyaromatic hydrocarbons. - Marine Pollution Bulletin 58: 256-262.

[4] Bacosa, H. P., Suto, K., Inoue, C. (2010): Preferential degradation of aromatic hydrocarbons in kerosene by a microbial consortium. - International Biodeterioration and Biodegradation 64: 702-710.

[5] Bacosa, H. P., Suto, K., Inoue, C. (2013): Degradation potential and microbial community structure of heavy oil-enriched microbial consortia from mangrove sediments in Okinawa, Japan. - Journal Environmental Science Health A 48: 1-12.

[6] Baldrian, P. (2008): Mini-review: wood-inhabiting ligninolytic basidiomycetes in soils: ecology and constraints for applicability in bioremediation. - Fungal Ecology 1: 4-12.

[7] Bautista, L. F., Sanz, R., Molina, M. C., González, N., Sánchez, D. (2009): Effect of different non-ionic surfactants on the biodegradation of PAH by diverse aerobic bacteria. - International Biodeterioration and Biodegradation 30: 1-10.

[8] Bento, F. M., Camargo, F. A., de, O., Okeke, B. C., Frankenberger Jr, W. T. (2005): Diversity of biosurfactant producing microorganisms isolated from soils contaminated with diesel oil. - Microbiological Research 160(3): 249-255.

[9] Bezalel, L., Hadar, Y., Fu, P. P., Freeman, J. P., Cerniglia, C. E. (1996): Initial oxidation products in the metabolism of pyrene, anthracene, fluorene, and dibenzothiophene by the White rot fungus Pleurotus ostreatus. - Applied of Environmental Microbiology 62(7): 2554-2559.

[10] Bezza, F., Beukes, M., Nkhalambayausi-Chirwa, E. (2015): Application of biosurfactant produced by Ochrobactrum intermedium $\mathrm{CN} 3$ for enhancing petroleum sludge bioremediation. - Process Biochemistry 50: 1911-1922.

[11] Boonchan, S., Britz, M. L., Stanley, G. A. (2000): Degradation and mineralization of high-molecular weight polycyclic aromatic hydrocarbons by defined fungal-bacterial cocultures. - Applied Environmental Microbiology 66: 1007-1019.

[12] Borneman, J., Skroch, P. W., O'sullivan, K. M., Palus, J. A., Rumjanek, N. G., Jansen, J. L., Nienhuis, J., Triplett, E. W. (1996): Molecular Microbial Diversity of an Agricultursl Soil in Wisconsin. - Appied and Environmental Microbiology 62(2): 1935-1943.

[13] Borras, E., Camanial, G., Sarra, M., Novotny, C. (2010): Effect of soil bacteria on the ability of polycyclic aromatic hydrocarbons (PAHs) removal by Trametes versicolor and Irpex lacteus from contaminated soil. - Soil Biology and Biochemistry 42: 2087-2093.

[14] Bouchez, M., Blanchet, D., Bardin, V., Haeseler, F., Vandecasteele, P. (1999): Efficiency of defined strains and of soil consortia in the biodegradation of polycyclic aromatic hydrocarbon (PAH) mixtures. - Biodegradation 10: 429-435.

[15] Brito, J. C., Santos, X., Pleguezuelos, J. M., Fahd, S., Llorente, G. A., Parella, X. (2006): Morphological variability of the Lataste's viper (Vipera latastei) and the Atlas dwarf viper (Vipera monticola): patterns of biogeographical distribution and taxonomy. Amphibia-Reptilia 27: 219-240.

[16] Cerqueira, V. S., Hollenbach, E. B., Maboni, F., Vainstein, M. H., Camargo, F. A. O., Peralba, M. C. R., Bento, F. M. (2011): Biodegradation potential of oily sludge by pure and mixed bacterial cultures. - Bioresource Technology 102: 11003-11010.

[17] Chagas-Spinelli, A. C. O., Kato, M. T., de Lima, E. S., Gavazza, S. (2012): Bioremediation of a tropical clay soil contaminated with diesel oil. - Journal of Environmental Management 113: 510-516.

[18] Chupungars, K., Rerngsamran, P., Thaniyavarn, S. (2009): Polycyclic aromatic hydrocarbons degradation by Agrocybe sp. CU-43 and its fluorene transformation. International Biodeterioration and Biodegradation 63: 93-99. 
[19] Colombo, M., Cavalca, L., Bernasconi, S., Andreoni, V. (2011): Bioremediation of polyaromatic hydrocarbon contaminated soils by native microflora and bioaugmentation with Sphingobium chlorophenolicum strain C3R: A feasibility study in solid and slurryphase microcosms. - International Biodeterioration and Biodegradation 65: 191-197.

[20] DeBruyn, J. M., Chewning, C. S., Sayler, G. S. (2007): Comparative quantitative prevalence of Mycobacteria and functionally abundant nidA, nahAc, and nagAc dioxygenase genes in coal tar contaminated sediments. - Environmental Science Technology 41: 5426-5432.

[21] Díaz-Ramírez, I. J., Escalante-Espinosa, E., Favela-Torres, E., Gutiérrez-Rojas, M., Ramírez-Saad, H. (2008): Design of bacterial defined mixture cultures for biodegradation of specific crude oil fractions, using population dynamics analysis by DGGE. International Biodeterioration and Biodegradation 62: 21-30.

[22] Federici, E., Leonardi, V., Giubilei, M. A., Quaratino, D., Spaccapelo, R., D’Annibale, A., Petruccioli, M. (2007): Addition of allochthonous fungi to a historically contaminated soil affects both remediation efficiency and bacterial diversity. - Applied Microbiology and Biotechnology 77(1): 203-211. DOI: 10.1007/s00253-007-1143-1.

[23] Frenzel, M., Scarlett, A., Rowland, S. J., Galloway, T. S., Burton, S. K., Lappin-Scott, H. M., Booth, A. M. (2010): Complications with remediation strategies involving the biodegradation and detoxification of recalcitrant contaminant aromatic hydrocarbons. Science of the Total Environment 408: 4093-4101.

[24] Furuno, S., Foss, S., Wild, E., Jones, K. J., Semple, K. T., Harms, H., Wick, L. Y. (2012): Mycelia promote active transport and spatial dispersion of polycyclic aromatic hydrocarbons. - Environmental Science Technology 46: 5463-5470.

[25] Gallego, J. L. R., García-Martínez, M. J., Llamas, J. F., Belloch, C., Peláez, A. I., Sánchez, J. (2007): Biodegradation of oil tank bottom sludge using microbial consortia. Biodegradation 18: 269-281.

[26] Ghazali, F. M., Rahman, R. N. Z. A., Salleh, A. B., Basri, M. (2004): Biodegradation of hydrocarbons in soil by microbial consortium. - International Biodeterioration and Biodegradation 54: 61-67.

[27] González, N., Simarro, R., Molina, M. C., Bautista, L. F., Delgado, L., Villa, J. A. (2011): Effect of surfactants on PAH biodegradation by a bacterial consortium and on the dynamics of the bacterial community during the process. - Bioresource Technology 102: 9438-9446.

[28] Greenwood, P. F., Wibrow, S., George, S. J., Tibbett, M. (2008): Sequential hydrocarbon biodegradation in a soil from arid coastal Australia, treated with oil under laboratory controlled conditions. - Organic Geochemistry 39: 1336-1346.

[29] Hatakka, A., 1994. Lignin-modifying enzymes from selected white-rot fungi: production and role in lignin degradation. - FEMS Microbiology Reviews 13: 125-135.

[30] Hollender, J., Althoff, K., Mundt, M., Dott, W. (2003): Assessing the microbial activity of soil samples, its nutrient limitation and toxic effects of contaminants using a simple respiration test. - Chemosphere 53: 269-275.

[31] Janbandhu, A., Fukelar, M. H. (2011): Biodegradation of phenanthrene using adapted microbial consortium isolated from petrochemical contaminated environment. - Journal of Hazardous Materials 187: 333-340.

[32] Johnsen, A. R., Karlson, U. (2004): Evaluation bacterial strategies to promote the biovailability of polycyclic aromatic hydrocarbons. - Applied Microbiology and Biotechnology 63(4): 452-459.

[33] Johnsen, A. R., Wick, L. Y., Harms, H. (2005): Principles of microbial PAH-degradation in soil. - Environmental Pollution 133: 71-84.

[34] Kim, Y. M., Ahn, C. K., Woo, S. H., Jung, G. Y., Park, J. M. (2009): Synergic degradation of phenanthrene by consortia of newly isolated bacterial strains. - Journal of Biotechnology 144: 293-298. 
[35] Kohlmeier, S., Smits, T. H. M., Ford, R. M., Keel, C., Harms, H., Wick, L. (2005): Taking fungal highway: mobilization of pollutant degrading bacteria by fungi. Environmental Science Technology 39: 4640-4646.

[36] Li, X. J., Li, P. J., Lin, X., Zhang, C. G., Li, Q., Gong, Z. Q. (2008): Biodegradation of aged polycyclic aromatic hydrocarbons (PAHs) by microbial consortium in soil and slurry phases. - Journal of Hazardous Materials 150: 21-26.

[37] Liu, P. W. G., Chang, T. C., Whang, L. M., Kao, C. H., Pan, P. T., Cheng, S. S. (2011): Bioremediation of petroleum hydrocarbon contaminated soil: effects of strategies and microbial community shift. - International Biodeterioration and Biodegradation 65: 11191127.

[38] Lors, C., Damidot, D., Ponge, J. F., Périé, F. (2012): Comparison of a bioremediation process of PAHs in a PAH-contaminated soil at field and laboratory scales. Environmental Pollution 165: 11-17.

[39] Luo, Y. R., Tian, Y., Huang, X., Yan, C. L., Hong, H. S., Lin, G. H., Zheng, T. L. (2009): Analysis of community structure of a microbial consortium capable of degrading benzo(a)pyrene by DGGE. - Marine Pollution Bulletin 58: 1159-1163.

[40] Mamma, D., Kalogeris, E., Papadopoulos, N., Dimitris, G., Hatzinikolaou, Christrakopoulos, P., Kekos, D. (2004): Biodegradation of phenol by acclimatized Pseudomonas putida cells using glucose as an added growth substrate. - Journal Environmental Scientific Health A 39(8): 2093-2104.

[41] Mao, J., Luo, Y., Teng, Y., Li, Z. (2012): Bioremediation of polycyclic aromatic hydrocarbon-contaminated soil by a bacterial consortium and associated microbial community changes. - International Biodeterioration and Biodegradation 70: 141-147.

[42] Molina, M. C., González, N., Bautista, L. F., Sanz, R., Simarro, R., Sánchez, I., Sanz, J. L. (2009): Isolation and genetic identification of PAH degrading bacteria from a microbial consortium. - Biodegradation 20: 789-800.

[43] Mueller, J. G., Chapman, P. J., Pritchard, P. H. (1989): Action of a fluoranthene-utilizing bacterial community on polycyclic aromatic hydrocarbon components of creosote. Applied and Environmental Microbiology 55: 3085-3090.

[44] Namhyum, C., Lee, I. S., Song, H. S., Bang, W. G. (2000): Mechanisms used by white rot fungus to degrade lignin and toxic chemicals. - Journal of Microbiology and Biotechnology 10(6): 737-752.

[45] Ruberto, A. M., Vazquez, S. C., Curtosi, A. (2006): Phenanthrene biodegradation in soils using an Antartic bacterial consortium. - Bioremediation Journal 10: 191-201.

[46] Sack, U., Hofrichter, M., Fritsche, W. (1997): Degradation of polycyclic aromatic hydrocarbons by manganese peroxidese of Nemalotonoma frowardii. - FEMS Microbiology Letters 152: 227-234.

[47] Sahoo, N. K., Ramesh, A., Pakshirajan, K. (2012): Bacterial degradation of aromatic xenobiotic compounds: an overview on metabolic pathways and molecular approaches. Microorganisms in Environmental Management 201-220.

[48] Sambrook, J., Roussell, D. (2001): Molecular Cloning. A Laboratory manual. - Cold Spring Harbor Laboratory Press, Cold Spring Harbor, NY.

[49] Sinha, S., Chattopadhyvy, P., Sen, S. K. (2012): Microbial Degradation of Recalcitrant PAHs-Microbial Degradation of Xenobiotics. - Springer, Berlin, pp. 395-410. http://dx.doi.org/10.1007/978-3.

[50] Šnajdr, J., Dobiá_sová, P., V_etrovský, T., Valá_sková, V., Alawi, A., Boddy, L., Baldrian, P. (2011): Saprotrophic basidiomycete mycelia and their interspecific interactions affect the spatial distribution of extracellular enzymes in soil. - FEMS Microbiology Ecology 78: 80-90.

[51] Sultan, S., Hasnain, S. (2007): Reduction of toxic hexavalent chromium by Ochrobactrum intermedium strain SDCr-5 stimulated by heavy metals. - Bioresource Technology 98: 340-344. 
[52] Tian, Y., Liu, H. J., Zheng, T. L., Kwon, K. K., Kim, S. J., Yan, C. L. (2008): PAHs contamination and bacterial communities in mangrove Surface sediments of the Jiulong River Estuary, China. - Marine Pollution Bulletin 57(1): 707-715.

[53] Tirado-Torres, D., Gayosso-Canales, M., Marmolejo-Santillán, Y., Romo-Gómez, C., Acevedo-Sandoval, O. (2016): Removal of polycyclic aromatic hydrocarbons by Pleurotus ostreatus sp. ATCC38540 in liquid medium. - Academia Journal of Scientific Research 4(10): 376-379. DOI: 10.15413/ajsr.2016.0406.

[54] Tirado-Torres, D., Acevedo-Sandoval, O., Rodríguez-Pastrana, B. R., Gayosso-Canales, M. (2017): Phylogeny and polycyclic aromatic hydrocarbons degradation potential of bacteria isolated from crude oil-contaminated site. - Journal of Environmental Science and Health, Part A 9(52): 897-904. DOI: 10.15413/ajsr.2016.0406.

[55] Toledo, F. L., Calvo, C., Rodelas, B., González-Lopez, J. (2006): Selection and identification of bacteria isolated from waste crude oil with polycyclic aromatic hydrocarbons removal capacities. - Systematic and Applied Microbiology 29(3): 244252.

[56] Tornberg, K., Bååth, E., Olsson, S. (2003): Fungal growth and effects of different wood decomposing fungi on the indigenous bacterial community of polluted and unpolluted soils. - Biology and Fertility of Soils 37(3): 190-197. DOI: 10.1007/s00374-002-0574-1.

[57] Valentín, L., Feijoo, G., Moreira, M. T., Lema, J. M. (2006): Biodegradation of polycyclic aromatic hydrocarbons in forest and salt marsh soils by White-rot fungi. International Biodeterioration and Biodegradation 58: 15-21.

[58] Venosa, A. D., Zhu, X. (2003): Biodegradation of crude oil contaminating marine shorelines and freshwater wetlands. - Spill Science and Technology Bulletin 8: 163-178.

[59] Vila, J., Nieto, J. M., Mertens, J., Springael, D., Grifoll, M. (2010): Microbial community structure of a heavy metal fuel oil-degrading marine consortium: linking microbial dynamics with polycyclic aromatic hydrocarbon utilization. - FEMS Microbiology Ecology 73: 249-362.

[60] Wang, J., Xu, H., Guo, S. (2008): Isolation and characteristics of a microbial consortium for effectively degrading phenanthrene. - Petroleum Science 4(3): 68-75.

[61] Waranusantigul, P., Lee, H., Kruatrachue, M., Pokethitiyook, P., Auesukaree, C. (2011): Isolation and characterization of lead-tolerant Ochrobactrum intermedium and its role in enhancing lead accumulation by Eucaliptus camaldulensis. - Chemosphere 85: 584-590.

[62] Yuan, S. Y., Wei, S. H., Chang, B. V. (2002): Biodegradation of polycyclic hydrocarbons by mixed culture. - Chemosphere 41: 1463-1468.

[63] Zeng, J., Lin, X. G., Zhang, J., Li, X. Z. (2010): Isolation of polycyclic aromatic hydrocarbons (PAHs)-degrading Mycobacterium spp. and the degradation in soil. Journal of Hazardous Materials 183: 718-723. 